\title{
Pelatihan Manajemen Pemeliharaan Itik Kerinci Menuju Kawasan Sentra Produksi Di Kabupaten Kerinci
}

\author{
Noferdiman $^{1}$, Yusma Damayanti ${ }^{2}$ \\ ${ }^{1}$ Pascasarjana Universitas Jambi \\ ${ }^{2}$ Fakultas Pertanian Universitas Jambi \\ Jl. Raya Jambi - Ma. Bulian Km. 15 Kampus Universitas Jambi, Mendalo Darat Jambi, Telp. \\ (0741) 582907 \\ E-mail: noferdiman@unja.ac.id
}

\begin{abstract}
The community service program (CSP) aims to: (1). Increase productivity of Kerinci ducks which are germplasm by utilizing the potential of food crops (rice bran) and plantation waste (palm kernel meal) which can be used as Kerinci duck feed resources with biotricho technology, (2). Increase Kerinci ducks population using breeding center technology with simple selection and hatching machines. The CSP activity was carried out by the method of active interaction between the implementers and the target groups involved in this activity, namely: Keluarga Damai and Maju Jaya Mandiri Farmers Group in Tanjung Harapan Village, Kerinci Regency. Some of the implemented programs are: (1). Conseling and training, including: biotricho technology, breeding center technology, utilizing potential local feed stuffs, duck rations, duck selection, and hatching machines, (2). Practicing directly the application of biotricho technology to make formulation of local feed stuffs and breeding center technology with hatching machine technology and simple selection of Kerinci ducks at the Farmer Group level. The results of the activity indicated that the CSP program can be implemented and responded well by the Farmers Group in Tanjung Harapan Village, Kerinci Regency and the implementation of the CSP program is very beneficial for farmers, and Implementing Institutions because it can be a medium to transfer Knowledge and Technology especially the local Kerinci duck which is not done much yet and is not focused. Therefore, the results of studies and the efforts to develop local Kerinci ducks in the countryside are not optimal.
\end{abstract}

Keywords: Farming Management, biotricho, breeding center, and Kerinci duck

\begin{abstract}
Abstrak
Program pengabdian pada masyarakat (PPM) ini bertujuan: (1). untuk meningkatkan produktivitas ternak itik Kerinci yang merupakan plasma nutfah dengan memanfaat potensi limbah tanaman pangan (dedak padi) dan limbah perkebunan (bungkil inti sawit) yang dapat dimanfaatkan sebagai sumberdaya pakan itik Kerinci dengan teknologi biotricho, dan (2). untuk meningkatkan populasi itik Kerinci dengan teknologi breeding center dengan proses seleksi bibit sederhana dan mesin tetas. Kegiatan PPM ini dilakukan dengan metode interaksi aktif antara pelaksana kegiatan dengan kelompok sasaran yang terlibat dalam kegiatan ini yaitu: Kelompok Tani Keluarga Damai dan Kelompok Tani Maju Jaya Mandiri di Desa Tanjung Harapan Kabupaten Kerinci. Beberapa program yang dilaksanakan adalah : (1). penyuluhan dan pelatihan, mencakup: teknologi biotricho, teknologi breeding center, potensi bahan pakan lokal, ransum itik, seleksi bibit, dan mesin tetas, (2). praktek langsung penerapan teknologi biotricho bahan pakan lokal untuk pembuatan ransum itik Kerinci dan teknologi breeding center dengan teknologi mesin tetas dan seleksi sederhana bibit itik Kerinci di tingkat Kelompok Tani. Hasil kegiatan menunjukkan bahwa program PPM dapat dilaksanakan dan direspon dengan baik oleh Kelompok Tani di Desa Tanjung Harapan Kabupaten Kerinci dan pelaksanaan program PPM ini sangat bermanfaat bagi peternak, dan Institusi Pelaksana karena dapat menjadi menjadi media transfer Ilmu pengetahuan dan Teknologi khususnya itik lokal Kerinci yang selama ini masih kurang banyak dilakukan dan tidak terfokus, sehingga tidak optimal dalam hasil kajian dan usaha pengembangan itik lokal Kerinci di pedesaan.
\end{abstract}

Kata kunci : Manajemen pemeliharaan, biotricho, breeding center, dan itik Kerinci 


\section{PENDAHULUAN}

Populasi ternak itik di Provinsi Jambi menunjukkan peningkatan yang menggembirakan, dimana pada tahun 2011 berjumlah 799.314 ekor dan meningkat 38,98 \% pada tahun 2016 menjadi 1.310.110 ekor dan produksi telur mencapai 2.577.107 kg (BPS Provinsi Jambi, 2017), dimana hampir $50 \%$ populasi dan produksi telur itik berasal dari Kabupaten Kerinci. Pemeliharaan itik di Kabupaten Kerinci pada umumnya menggunakan itik Kerinci, dimana itik ini merupakan salah satu unggas lokal potensial yang umumnya dipelihara masyarakat di pedesaan sebagai penghasil telur (tetas ataupun konsumsi). Menurut Adrizal (2004) melaporkan bahwa itik Kerinci secara formal belum masuk ke dalam dokumen FAO, dan hal ini sangat mungkin karena belum tersedianya data yang memadai mengenai itik Kerinci. Sementara itu itik Kerinci sebagai plasma nutfah ternak lokal perlu dipertahankan, dan produksi utama dari itik ini adalah telur. Berkurangnya populasi itik galur murni itik Kerinci disebabkan banyaknya peternak yang mendatangkan bibit dari luar terutama dari pulau Jawa, untuk memenuhi permintaan daging dan telur yang terus meningkat. (Manin, dkk., 2014). Akibat pemeliharaan itik di sentra pengembangan dilakukan secara ekstensif (digembalakan), maka perkawinan silang antara itik galur murni Kerinci dengan jenis itik lainnya tidak dapat dihindarkan dan sulit untuk dikendalikan. Hal ini akan menjadi ancaman bagi kelestarian genetik itik Kerinci karena akan terjadi perkawinan silang yang dikhawatirkan gen-gen unggulan yang dimiliki oleh itik Kerinci lambat laun akan punah.

Pelaksanaan program pengabdian pada masyarakat (PPM) tahun 2018 di Desa Tanjung Harapan Cupak Kabupaten Kerinci dengan kegiatan penerapan teknologi biodegradasi bahan pakan lokal dan pembibitan itik Kerinci dengan tujuan untuk meningkatkan produktivitas ternak itik Kerinci dengan memanfaat potensi limbah tanaman pangan (dedak padi) dan limbah perkebunan (bungkil inti sawit) yang dapat dimanfaatkan sebagai sumberdaya pakan itik Kerinci yang dapat diperbaharui (renewable resource), meningkatan pengetahuan dan ketrampilan petani peternak itik dalam membuat teknologi mesin tetas dengan kapasitas yang lebih besar dengan mudah dan biaya yang lebih murah, serta untuk meningkatan pengetahuan petani peternak itik tentang standar mutu produksi ternak itik (kualitas telur itik) dan mutu bibit itik hasil mesin tetas, sehingga mempunyai daya saing yang lebih baik untuk menjual produknya dan memberi kontribusi pendapatan yang lebih baik.

Jumlah ternak itik yang dipelihara oleh Kelompok Tani Keluarga Damai pada awalnya berjumlah 324 ekor (tahun 2013) dan meningkat pada tahun 2017 menjadi 420 ekor, peningkatan jumlah populasi itik yang dipelihara hanya sebesar $29,63 \%$. Rendahnya peningkatan populasi itik selama 4 tahun pemeliharaan ini dikarenakan oleh adanya fluktuasi populasi itik setiap tahunnya, fluktuasi ini akibat dari penjualan ternak itik yang sudah afkir (tidak produktif) dan pembelian itik baru yang sesuai dengan modal Kelompok Tani yang tersedia, dimana untuk penggembangan usaha ternak itik masih terbatas dengan permodalan. Sedangkan Kelompok Tani Maju Jaya Bersama berusaha dibidang penyediaan bibit itik melalui penetasan telur itik untuk dijadikan anak itik (DOD). Penetasan telur yang dilakukan masih skala kecil dengan kapasitas mesin tetas hanya 100 - 200 butir. Padahal dilihat dari segi permintaan anak itik cukup besar, dimana per bulan saja bisa mencapai 500 - 700 ekor. Sedangkan Kelompok Tani ini hanya mampu menyediakan bibit itik sebanyak 100 ekor per bulannya (tahun 2015). Bila dihitung secaranominal pendapatan dari penjualan anak itik dengan harga per ekor Rp 6.000,-maka Kelompok Tani memperoleh Rp 840.000 ,-per bulan. Kondisi ini menggambarkan potensi usaha pembibitan itik melalui mesin tetas sangat berpeluang untuk meningkatkan pendapatan petani peternak, apalagi dengan meningkatkan kapasitas mesin tetas dengan skala yang lebih besar (1.000 butir).

Bila dilihat dari potensi petani peternak, sumberdaya bahan pakan lokal, inftrastruktur kedekatan sumberdaya dan peluang pasar, maka Kelompok Tani ini sangat potensial dikembangkan dan dijadikan wilayah unggulan pengembangan itik di Kabupaten Kerinci. Sasaran yang ingin dicapai dari kegiatan ini adalah: tersedianya ransum itik yang murah dan efisien berbasis sumber bahan pakan lokal dengan teknologi biodegradasi jamur Trichoderma sp., (Biotricho), peningkatan produksi telur itik dengan biaya produksi yang lebih murah, tercapainya standar mutu produksi telur dan standar bibit itik (DOD) untuk pengembangan wilayah budidaya yang berkelanjutan (Breeding Center), peningkatan daya saing penjualan produk telur itik dan bibit itik (DOD) lebih kompetitif di tingkat petani peternak, peningkatan pengolahan bahan pakan ternak 
dengan pembuatan unit penggilingan, pencampuran beberapa bahan pakan, serta cara pemberian pada ternak itik, dan meningkatkannya pendapatan petani peternak itik.

\section{METODE}

Kegiatan PPM ini dilakukan dengan metode interaksi aktif antara pelaksana kegiatan dengan kelompok sasaran yang terlibat dalam kegiatan ini yaitu: Kelompok Tani Keluarga Damai dan Kelompok Tani Maju Jaya Mandiri di Desa Tanjung Harapan Cupak Kabupaten Kerinci. Kelompok Tani ini masing-masing beranggota 15 petani peternak yang merupakan pengelola usaha peternakan itik dan pembibitan itik. Pendekatan pada metode ini diharapkan kelompok sasaran dapat menguasai proses alih teknologi biotricho dan breeding center sebagai sumber penggerak utama (prime mover) untuk peningkatan produktivitas dan populasi itik Kerinci. Beberapa program yang ditawarkan untuk pencapaian target penerapan teknologi produksi dan populasi itik Kerinci: (1). penyuluhan dan pelatihan, dimana materi pelatihan mencakup: teknologi biotricho, teknologi breeding center, potensi bahan pakan lokal, ransum itik, seleksi bibit, mesin tetas, dan itik Kerinci yang merupakan plasma nutfah. (2) partisipatif aktif anggota Kelompok Tani dengan pembentukan Layanan Konsultasi Teknis (LKT) yang merupakan forum konsultasi dan dialog antara tim PPM dengan petani peternak itik. (3), praktek lansung penerapan teknologi biotricho bahan pakan lokal untuk pembuatan ransum itik Kerinci dan teknologi breeding center dengan teknologi mesin tetas dan seleksi sederhana bibit itik Kerinci di tingkat Kelompok Tani, serta (4). pelaksanaan monitoring dan evaluasi (Monev) pelaksanaan program PPM pada Kelompok Tani. Materi pelaksanaan penyuluhan dan pelatihan dapat dilihat pada Tabel 1 dibawah ini.

Tabel 1. Penyuluhan dan pelatihan teknis PPM di Desa Tanjung Harapan Cupak Kerinci.

Materi Penyuluhan

Teknologi Biotricho Bahan Pakan DP + BIS Bio.

\section{Jenis Kegiatan}

1. Potensi dan kualitas bahan pakan lokal potensial.

2. Penggunaan jamur Trichoderma sp., dalam proses biodegradasi.

3. Cara membuat bahan pakan lokal dengan teknologi biodegradasi.

Menyusun Ransum Itik 1. Pemilihan bahan-bahan pakan lokal untuk itik.

Berbasis Bahan-Bahan Pakan 2. Penggunaan bahan pakan lokal hasil biodegradasi.

Lokal

3. Menyusun ransum itik dengan metode sederhana.

\begin{tabular}{ll}
\hline Manajemen Pemberian & 1. Cara pemberiaan pakan yang efisien (jumlah dan frekuensi). \\
Pakan untuk itik & 2. Penempatan tempat pakan dan minum. \\
& 3. Sanitasi pakan. \\
\hline Manajemen Pemeliharaan & 1. Pemeliharaan Periode Starter \\
Anak Itik (DOD) dan & 2. Pemeliharaan Periode Layer. \\
Dara/Petelur & \\
\hline Teknologi Penetasan Telur & 1. Model mesin tetas \\
Itik & 2. Cara membuat mesin tetas. \\
& 3. Karakteristik telur tetas. \\
& 4. Cara melaksanakan penetasan telur. \\
& 5. Penanganan telur yang menetas \\
\hline Seleksi Bibit Itik Lokal & 1. Cara seleksi bibit itik Lokal Kerinci (DOD). \\
Kerinci & 2. Cara seleksi bibit yang baik. \\
\hline Pemasaran Produksi Itik & 1. Cara pemasaran telur, itik jantan, dan itik afkir. \\
& 2. Cara pemasaran bibit itik (DOD). \\
\hline
\end{tabular}

Penyuluhan dan pelatihan bertujuan untuk meningkatkan pengetahuan petani ternak itik dalam manajemen pemeliharaan ternak itik, terutama: masalah bibit, pakan, dan pemeliharaan. 
Beberapa materi yang disampaikan sudah mampu mengatasi masalah petani ternak dalam mengembangkan usahanya, seperti : menyusun ransum berbasis pakan lokal yang efisien dan murah, teknologi penetasan telut itik yang digunakan untuk produksi bibit itik Kerinci, dan pemasaran produk yang digunakan untuk membuat jalur tata niaga penjualan produksi, sehingga mampu bertahan dan berkelanjutan.

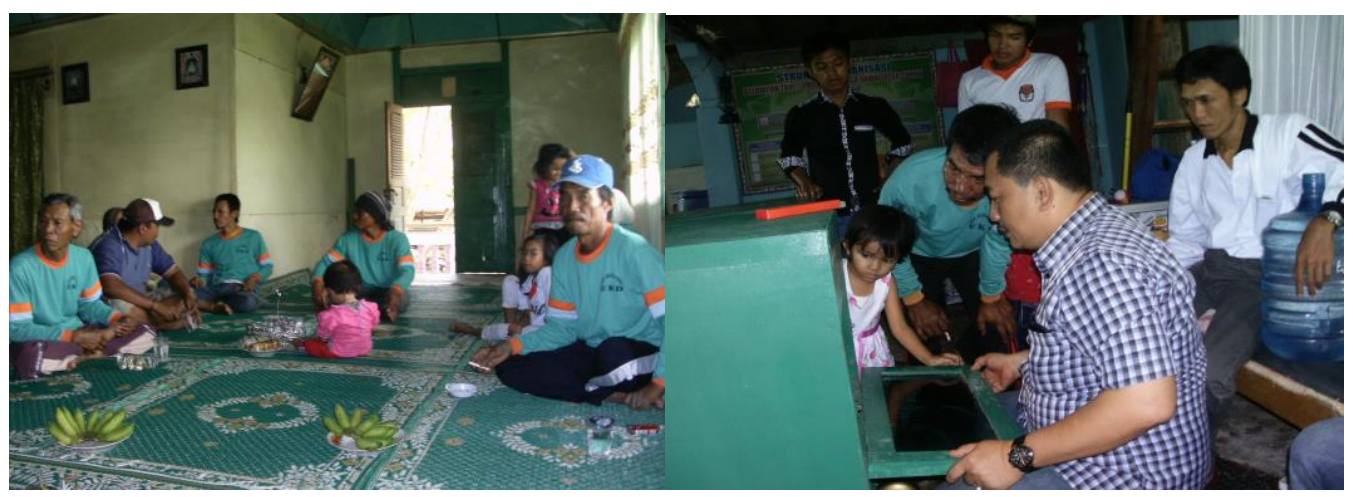

Gambar 1. Penyuluhan dan Pelatihan Penggunaan Mesin Tetas Telur

\section{HASIL DAN PEMBAHASAN}

\section{Pelaksanaan Penyuluhan dan Pelatihan Pemeliharaan Itik.}

Evaluasi keberhasilan pelatihan dilakukan untuk mengetahui tingkat pengetahuan peternak sebelum dilakukan pelatihan dan pada akhir dilakukan pelatihan, pengetahuan yang dievaluasi meliputi: pengetahuan tentang itik lokal Kerinci, teknologi biodegradasi, pembuatan bungkil inti sawit fermentasi, menyusun ransum itik, manajemen pemberian pakan itik. Evaluasi ini dilakukan untuk melihat sejauh mana keberhasilan dari pelaksanaan kegiatan yang dilakukan, sehingga dari evaluasi ini akan diketahui batas pengetahuan, keterampilan peserta pelatihan, serta kegiatan apa lagi yang akan dilakukan untuk menunjang keberhasilan yang telah dicapai dan target pelatihan sesuai dengan tujuan yang telah ditetapkan. Evaluasi tingkat pengetahuan peserta pelatihan dapat dilhat pada Tabel 2 .

Berdasarkan Tabel 2 menunjukkan bahwa tingkat pengetahuan peserta pelatihan mengalami peningkatan dari beberapa aspek materi penyuluhan yang disampaikan dan di kategorikan berhasil. Tingkat pengetahuan tentang bibit itik berkategori baik, dimana tingkat pengetahuan sebelum melakukan penyuluhan hanya 55,00 \% dan meningkat menjadi $70,00 \%$, keadaan ini menunjukkan bahwa peserta pelatihan telah mengetahui ciri-ciri bibit itik yang baik, mengetahui potensi itik untuk bibit, petelur dan pedaging, serta mengetahui keunggulan produksi itik lokal Kerinci. Sedangkan untuk aspek bahan-bahan pakan lokal tingkat pengetahuan juga meningkat dari 45,00 \% menjadi 75,00\%, artinya peserta pelatihan sudah mengetahui beberapa macam bahan-bahan pakan lokal seperti: jagung, dedak padi, bungkil kelapa, tepung bekicot, bungkil inti sawit, serta mengetahui potensi, kualitas zat-zat gizi, dan batas penggunaannya dalam ransum itik. Tingkat pengetahuan petani akan dipengaruhi oleh kematangan umur dan pengalaman, sesuai pendapat Dewi dan Wawan (2010) semakin cukup umur, tingkat kematangan, dan kekuatan seseorang akan lebih matang dalam berpikir dan bekerja untuk lebih memahami sesuatu hal yang baru.

Tabel 2. Hasil Evaluasi Tingkat Pengetahuan Peserta Penyuluhan dan Pelatihan.

\begin{tabular}{clccc}
\hline No. & \multicolumn{1}{c}{ Materi Penyuluhan } & \multicolumn{2}{c}{ Tingkat Pengetahuan (\%) } \\
\cline { 3 - 4 } & & Sebelum Pelatihan & Setelah Pelatihan \\
\hline 1. & Pengetahuan Bibit Itik & 55,00 & 70,00 \\
\hline 2. & $\begin{array}{l}\text { Pengetahuan } \\
\text { Lokal }\end{array}$ & 45,00 & 75,00 \\
\hline 3. & $\begin{array}{l}\text { Pengetahuan Limbah Sawit/Bungkil } \\
\text { Inti Sawit }\end{array}$ & 35,00 & 65,00 \\
\hline
\end{tabular}




\begin{tabular}{clcc}
\hline 4. & Pengetahuan Teknologi Biotricho & 35,00 & 70,00 \\
\hline 5. & Pengetahuan Penyusunan Ransum Itik & 45,00 & 75,00 \\
\hline 6. & $\begin{array}{l}\text { Pengetahuan Manajemen Pemberian } \\
\text { Pakan Itik }\end{array}$ & 45,00 & 70,00 \\
\hline 7. & $\begin{array}{l}\text { Pengetahuan Manajemen } \\
\text { Pemeliharaan itik }\end{array}$ & 55,00 & 80,00 \\
\hline 8. & Pengetahuan Penetasan Telur Itik & 30,00 & 65,00 \\
\hline
\end{tabular}

Tingkat pengetahuan tentang limbah sawit dan bungkil inti sawit sebelum dilakukannya pelatihan hanya $35,00 \%$ dan meningkat menjadi $65,00 \%$ setelah dilakukannya pelatihan, keadaan ini menunjukkan bahwa peserta pelatihan sudah mengetahui tentang asal limbah sawit/bungkil inti sawit, kualitas limbah sawit/bungkil inti sawit, pengolahan bungkil inti sawit menjadi bahan pakan dan batas penggunaan bungkil inti sawit dalam ransum itik. Sedangkan untuk pengetahuan teknologi fermentasi hanya 35,00\% sebelum pelatihan dan meningkat menjadi 70,00\% setelah pelatihan, artinya peserta pelatihan sudah mengetahui cara-cara melakukan pembuatan bungkil inti sawit fermentasi dengan baik.

Sedangkan untuk cara menyusun ransum itik tingkat pengetahuan juga meningkat dari $50,00 \%$ menjadi $75,00 \%$, artinya peserta pelatihan sudah mengetahui beberapa cara-cara sederhana menyusun ransum untuk itik dengan menggunakan bahan-bahan pakan lokal dan bungkil inti sawit fermentasi. Peserta juga telah mengetahui tentang faktor-faktor yang perlu diperhatikan dalam menyusun ransum itik seperti: kebutuhan gizi untuk itik, kualitas bahan-bahan yang akan disusun menjadi ransum, batas-batas penggunaan bahan pakan dalam penyusunan ransum, ketersediaan bahan-bahan pakan, harga bahan pakan, dan tipe ransum yang akan dibuat. Untuk manajemen pemberian pakan itik, peserta pelatihan sudah mengetahui tentang cara pemberian ransum yang efisien, bentuk ransum, jumlah yang harus diberikan, waktu pemberian ransum, dan perhitungan jumlah konsumsi ransum terhadap bobot badan dan produksi telur yang dihasilkan.

Pengetahuan tentang penetasan telur itik dengan menggunakan mesin tetas masih rendah $30,00 \%$, karena selama ini belum pernah dilakukan oleh petani peternak. Setelah melakukan pelatihan, pengetahuan petani peternak meningkat menjadi $65,00 \%$ artinya petani telah mengetahui tentang cara membuat mesin tetas dan cara pengelolaan telur tetas menjadi bibit itik lokal Kerinci. Petani maupun peternak yang berusia produktif memiliki kemampuan bekerja dan berfikir yang lebih tinggi dibanding dengan tidak produktif (Ismaili,dkk.,. 2015). Pernyataan ini sesuai dengan penelitian Riyadi (2003) bahwa umur yang matang sangat menentukan kemampuan dan kemauan petani untuk menerapkan teknologi.

\section{Perkembangan Usaha Pemeliharaan Ternak Itik}

Dalam pelaksanaan program PPM tahun 2018 hingga pelaporan akhir ini telah diberikan itik Kerinci sejumlah 120 ekor, dengan jenis kelamin untuk itik dara siap produksi 100 ekor dan itik jantan dewasa 20 ekor. Itik ini dipelihara secara manajemen kelompok oleh Kelompok Tani Keluarga Damai. Pada awal bulan Agustus 2018, itik sudah mulai bertelur dengan produksi telur mencapai $30 \%$ untuk pemberian itik tahap I, artinya kelompok Tani telah mampu menghasilkan 21 butir telur itik Kerinci per hari (70 ekor induk x $30 \%)$, jika dikalkulasi per bulan produksi telur $60 \%$ maka jumlah telur itik dalam bulan Agustus 2018 mencapai 378 butir/bulan (60\% x 30 hari x 21 butir). Dengan harga telur ditingkat petani dengan Rp 2.000,- karena telur awal dapat dijual oleh Kelompok Tani sehingga penerimaan uang Rp 756.000,-./bulan 
Tabel 3. Perkembangan usaha ternak Itik Kerinci pada Kelompok Tani Keluarga Damai Tahun Pelaksanaan 2018.

\begin{tabular}{|l|c|c|c|c|c|}
\hline Bulan & $\begin{array}{c}\text { Jumlah Itik } \\
\text { Betina } \\
\text { Produktif } \\
\text { (ekor) }\end{array}$ & $\begin{array}{c}\text { Produksi Telur } \\
\text { (butir/bulan) }\end{array}$ & $\begin{array}{c}\text { Penjualan } \\
\text { (Rp) }\end{array}$ & $\begin{array}{c}\text { Biaya } \\
\text { Ransum } \\
(\text { Rp) }\end{array}$ & $\begin{array}{c}\text { Penerimaan } \\
\text { (Rp) }\end{array}$ \\
\hline Agustus & 70 & $378(30 \%)$ & 756.000 & 1.050 .000 & -294.000 \\
\hline September & 100 & $912(50 \%)$ & 1.824 .000 & 1.560 .000 & 264.000 \\
\hline Oktober & 99 & $1.209(74 \%)$ & 2.418 .000 & 1.545 .000 & 873.000 \\
\hline
\end{tabular}

Bila dihitung dengan penggunaan ransum dengan menyusun sendiri, yaitu Dedak Halus (10\%), Jagung Halus (30\%), BIS Biotricho (20\%) dan Konsentrat (40\%), campuran dari keempat bahan ini yang diaduk setiap hari dan diberikan ke itik Kerinci, dengan kandungan gizi mengandung protein kasar $20 \%$ dan Energi Metabolis $2960 \mathrm{kkal} / \mathrm{kg}$. Harga ransum hanya Rp 5.000 ,- per kg. Untuk 70 ekor itik menghabiskan $210 \mathrm{~kg}$ ransum per bulan, berarti per bulan biaya ransum Rp. 882.000,- (210 kg x Rp 5.000,-). Produksi telur dan keuntungan per bulan dapat dilihat pada Tabel 3.

Tujuan pemeliharaan itik betina produktif ini memang itu menghasilkan telur, oleh karena itu Kelompok Tani cenderung menggunakan sumberdaya yang ada seoptimal mungkin, seperti kontruksi kandang, kebutuhan nutrisi itik saat bertelur, sanitasi, dan kesehatan ternak itik. Sehingga diharapkan produksi telur bisa mencapai maksimal, jika dihitung persentase produksi telur selama 3 bulan terakhir maka pada bulan Oktober baru bisa Kelompok Tani mendapatkan keuntungan yang lebih tinggi, karena pada bulan Agustus masih merugi dan saat itu memang produksi telur masih rendah yaitu $30 \%$, tetapi pada bulan Oktober sudah mulai untung tetapi belum optimal. Produksi telur per bulan dalam persen (\%) dapat dilihat pada Tabel 3. Perkembangan usaha ternak itik ini akan menentukan saatnya untung atau ruginya suatu usaha.

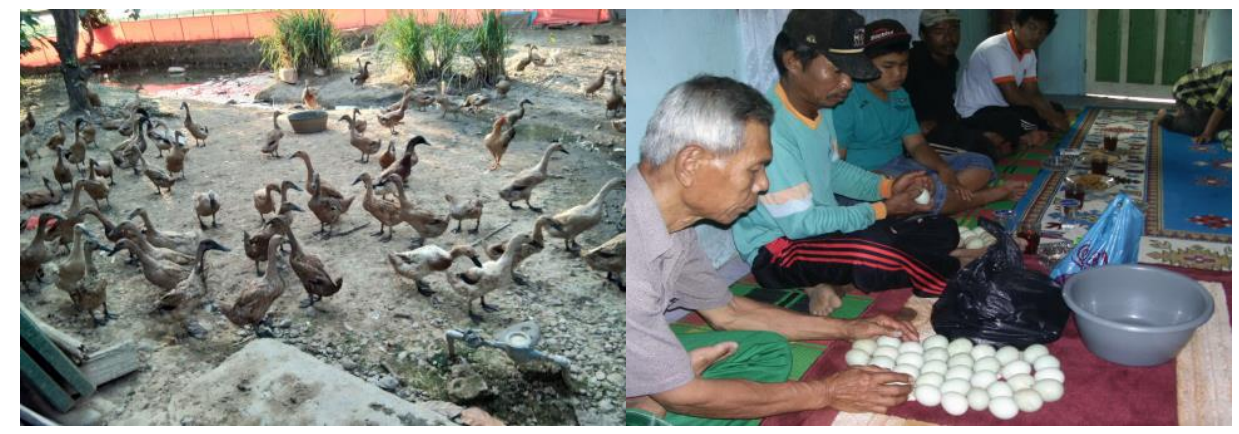

Gambar 2. Usaha Pemeliharan Itik dan Produksi Telur Itik

Sedangkan Kelompok Tani Maju Jaya berusaha dibidang penyediaan bibit itik melalui penetasan telur itik untuk dijadikan anak itik (DOD). Penetasan telur tahap I telah dilakukan sejak tanggal 2 Agustus 2018, dimana mesin tetas telah dioperasikan/uji coba dengan 200 butir telur tetas yang dimasukkan ke mesin tetas. Dari 200 butir telur tetas yang diujicobakan/praktek penggunaan mesin tetas, maka telur yang menetas mencapai 130 butir dengan daya tetas sebesar 65 $\%$ (Tabel 4).

Tabel 4. Perkembangan usaha penetasan telur itik di Kelompok Tani Maju Jaya TahunPelaksanaan 2018.

\begin{tabular}{lcccc}
\hline Bulan & $\begin{array}{c}\text { Jumlah Telur } \\
\text { Tetas (butir) }\end{array}$ & $\begin{array}{c}\text { Daya Tetas } \\
(\boldsymbol{\%})\end{array}$ & $\begin{array}{c}\text { Jumlah Yang } \\
\text { Menetas (ekor) }\end{array}$ & $\begin{array}{c}\text { Jumlah Anak Itik } \\
\text { Hidup (ekor) }\end{array}$ \\
\hline Agustus & 200 & 65 & 130 & 118 \\
\hline September & 325 & 78 & 254 & 246 \\
\hline Oktober & 400 & 80 & 325 & 320 \\
\hline
\end{tabular}


Penggunaan mesin tetas setiap penetasan 2 mesin tetas yang siap digunakan, karena lama penetasan telur itik bisa mencapai 28 hari, sehingga setiap bulan dapat digunakan 2 mesin tetas sekaligus. Penetasan telur itik tergolong usaha yang mudah dan sederhana, Kelompok Tani atau peternak yang telah memiliki pengetahuan Teknologi Penetasan tinggal menjalankan usahanya saja, karena peternak hanya mempersiapkan telur fertil dan menyalakan mesin tetas serta mengkondisikan temperatur tertentu, langsung memasukkan rak-rak berisi telur ke dalam mesin tersebut. Pada hari-hari berikutnya, peternak cukup mengontrol keadaan temperatur di dalam mesin tetas dan membalik-balikkan telur. Pada hari ke-27 - 30, telurpun sudah mulai menetas dan peternak siap menjual anak itik (DOD) yang dihasilkan.

Penetasan telur yang dilakukan oleh Kelompok Tani Maju Jaya telah menghasilkan mulai bulan Agustus 2018, dimana sudah mampu menyisihkan dana investasi ke Kelompok Tani, sebagaimana terlihat pada hasil penjualan dibawah ini. Penjualan anak itik (DOD) dapat dilihat pada Tabel 5 .

Tabel 5. Perkembangan usaha penetasan telur itik di Kelompok Tani Maju Jaya TahunPelaksanaan 2018.

\begin{tabular}{lccc}
\hline Bulan & $\begin{array}{c}\text { Jumlah Anak Itik } \\
\text { Hidup (ekor) }\end{array}$ & Harga DOD (Rp) & $\begin{array}{c}\text { Penerimaan } \\
(\mathbf{R p})\end{array}$ \\
\hline Agustus & 118 & 9.000 & 1.062 .000 \\
\hline September & 246 & 9.000 & 2.214 .000 \\
\hline Oktober & 320 & 9.000 & 2.880 .000 \\
\hline
\end{tabular}

Dana investasi digunakan untuk modal awal perkembangan usaha penetasan berikutnya, sehingga dana investasi sangat diperlukan untuk keberlanjutan usaha ternak itik di Kelompok Tani, seperti : pembelian mesin tetas baru. Semakin banyak telur yang ditetaskan maka semakin tinggi penerimaan yang terkumpul, sehingga keberlanjutan usaha akan lebih terjamin. Jika dihitung ratarata daya tetas telur $80 \%$ saja maka jumlah telur itik yang menetas dan anak itik yang hidup (DOD) bisa mencapai : 320 ekor per bulan dengan harga DOD per ekor Rp 9.000,-, maka penerimaan bisa mencapai $\mathrm{Rp} 2.880 .000,-$, bila sepakatan $20 \%$ dari penerimaan digunakan untuk dana investasi maka Kelompok Tani akan mendapat sebesar Rp 576.000,- per bulan. Dana investasi ini digunakan untuk mengembangkan usahanya terutama untuk perkembangan penetasan telur itik sehingga bisa lebih besar dan pada akhirnya pendapatan petani ternak itik juga lebih besar.

Usaha peternakan itik ini dapat dikembangkan menjadi pusat unggulan pengembangan suatu kawasan potensial, baik untuk breeding center maupun usaha pemeliharaan dengan tujuan produksi daging dan telur. Menurut Ahira (2011) kelompok tani ternak bukan hanya sekumpulan anggota yang mempunyai keinginan dan kepentingan bersama yang bergabung dalam sebuah wadah kelompok tani ternak, akan tetapi juga menjadikan kelompok sebagai sarana untuk pengembangan diri dalam berorganisasi dan pengembangan usaha ternaknya. Apabila kelompok tani ternak dapat berjalan sesuai dengan rumusan tujuan awal didirikan, maka tidak menutup kemungkinan akan tercapainya pengembangan kelompok tani ternak yang semakin baik melalui dukungan dari semua pihak termasuk pemerintah, sehingga pengembangan potensi kawasan unggulan akan terwujud.

\section{KESIMPULAN}

Berdasarkan hasil kegiatan pelaksanaan pengabdian pada masyarakat (PPM) dapat diambil beberapa kesimpulan sebagai berikut:

1. Program pengabdian pada masyarakat (PPM) tahun 2018 dapat dilaksanakan dan direspon dengan baik oleh Kelompok Tani Keluarga Damai dan Kelompok Tani Maju Jaya Bersama di Desa Tanjung Harapan Cupak Kabupaten Kerinci

2. Pelaksanaan program pengabdian pada masyarakat (PPM) ini sangat bermanfaat bagi peternak, dan Institusi Pelaksana karena dapat menjadi menjadi media transfer Ilmu pengetahuan dan 
Teknologi khususnya itik lokal Kerinci yang selama ini masih kurang banyak dilakukan dan tidak terfokus, sehingga tidak optimal dalam hasil kajian dan usaha pengembangan itik lokal Kerinci di pedesaan.

\section{UCAPAN TERIMA KASIH}

Penulis mengucapkan terima kasih kepada Rektor Universitas Jambi, Direktur Pascasarjana Universitas Jambi, serta Ketua LPPM Universitas Jambi yang telah memberi izin dan dukungan dana PNBP terhadap pelaksanaan pengabdian pada masyarakat ini.

\section{DAFTAR PUSTAKA}

[1] Adrizal, H. Nur, Z. Zakaria, and Yusrizal. 2004. Kerinci duck: Phenotypic characteristic and performance under scavenging. XXII World's Poultry Congress. Istanbul Turkey.

[2] Ahira. 2017. Fungsi Kelompok Tani Ternak. http://www.anneahira.com/kelompok-taniternak.htm. [21 April 2017].

[3] BPS, 2017. Statistik Indonesia. Badan Pusat Statistik, Jakarta.

[4] Dewi dan Wawan. 2010. Tingkat pengetahuan petani dalam penggunaan pupuk organic pada padi sawah. E- Jurnal Agrobisnis dan Agrowisata. Vol. 6 No. 4 Edisi Oktober 2017. Hal : 506 -512 .

[5] Gibson, T.S. and B.V. McCleary. 2003. A simple procedure for the lange scale purification of B-D-Xilanase from Tricoderma viride. Carbohydrate Polymer. Volume 7, Issue 3, p: 225-240. Available on line 25 April 2003.

[6] Hardjosworo, P.S., A. Setioko, P.P. Ketaren, L. H. Prasetyo, A.P. Sinurat dan Rukmiasih. 2001. Perkembangan teknologi peternakan unggas air di Indonesia. Prosiding Lokakarya Unggas Air, BPT Ciawi, Bogor.

[7] Iskandar, S. A.P. Sinurat, B.Tiesnamurti, dan A.Bamualim. 2008. Bungkil inti sawit potensial untuk pakan ternak. Warta Penelitian dan Pengembangan Pertanian. Vol.30. No.1;16-17.

[8] Ismilaili, Ninuk Purnaningsih, Pang S. Asngari. 2014. Tingkat Adopsi Inovasi Pengelolaan Tanaman Terpadu (PTT) Padi Sawah di Kecamatan Leuwiliang, Kabupaten Bogor. Jurnal Penyuluhan, Maret 2015 Vol. 11 No. 1.

[9] Jaelani, A dan N. Firahmi. 2007. Kualitas sifat fisik dan kandungan nutrisi bungkil inti sawit dari Berbagai proses pengolahan crude palm oil (CPO). Jurnal Al Ulum Vol.33 No 3; 1-7.

[10] Manin, F, Ella Hendalia, Haris Lukman dan Farhan. 2014. Pelestarian dan budi daya itik Kerinci sebagai plasma nutfah Provinsi Jambi berbasis Probio_FM di Kecamatan Air Hangat Kabupaten Kerinci Provinsi Jambi. Jurnal Pengabdian Masyarakat Universitas Jambi. Volume 33, Nomor 1 - 4 Januari - Juni 2014. Hal : 30 - 50.

[11] Noferdiman dan Zubaidah. 2012. Penggunaan Azolla microphylla fermentasi dalam ransum broiler. Prosiding Seminar Nasional dan Rapat Tahunan Bidang Ilmu-Ilmu Pertanian BKSPTN Wilayah Barat Tahun 2012, Fakultas Pertanian Universitas Sumatera Utara, Medan. Hal : $792-799$.

[12] Riyadi. 2003. Hubungan antara Hasil Pelatihan dengan Tingkat Penerapan Padi Sawah di Kalimantan Timur. [tesis]. Bogor (ID): Sekolah Pascasarjana, Institut Pertanian Bogor. 